\title{
Chitosan Nanoparticle of hCG (Human Chorionic Gonadotrophin) Hormone in Increasing Induction of Dairy Cattle Ovulation
}

\author{
Pamungkas FA, Sianturi RG, Wina E, Kusumingrum DA \\ ${ }^{1}$ Indonesian Research Institute for Animal Production, PO Box 221, Bogor 16002 \\ E-mail: fitrap@yahoo.com
}

(received 29-12-2015; revised 08-03-2016; 25-03-2016)

\begin{abstract}
ABSTRAK
Pamungkas FA, Sianturi RG, Wina E, Kusumaningrum DA. 2016. Nanopartikel chitosan hormon hCG (Human Chorionic Gonadotrophin) dalam meningkatkan induksi ovulasi pada sapi perah. JITV 21(1): 34-40. DOI: http://dx.doi.org/10.14334/jitv.v21i1.1343

Suatu sistem rilis hormon hCG (human chorionic gonadotropin) yang terkontrol membantu mengatasi degradasi hormon hCG yang cepat dalam darah dan menghindari penggunaan injeksi hormon berkali-kali untuk tujuan induksi ovulasi serta meningkatkan efektifitas reproduksi. Penelitian bertujuan mempersiapkan nanopartikel chitosan hormon hCG (CS-NPh) serta mengetahui efektifitas penggunaannya melalui nasal spray. Paramater yang diamati meliputi karakteristik sifat fisikokimia CS$\mathrm{NPh}$ dan pengamatan ukuran folikel, korpus luteum, waktu ovulasi dan onset berahi setelah pemberian CS-NPh secara nasal spray dibandingkan dengan hCG secara intramuskular (kontrol) dengan dosis $1.000 \mathrm{IU}$ pada sapi perah. Hasil penelitian menunjukkan bahwa karakteristik sifat fisikokimia CS-NPh masih dalam rentang ukuran nanopartikel dengan distribusi massa molekul yang baik dan lebih stabil, sehingga dapat digunakan sebagai komponen pembawa hormon. Hasil penelitian diperoleh bahwa waktu ovulasi setelah pemberian hormon hCG secara intramuskular (hari ke 3,13 $\pm 0,35$ ) dan CS-NPh secara nasal spray (hari ke 3,33 $\pm 0,49$ ) dengan ukuran folikel yang diovulasikan berturut-turut sebesar 1,62 $\pm 0,22$ dan $1,76 \pm 0,28 \mathrm{~cm}$ tidak menunjukkan perbedaan yang nyata $(\mathrm{p}>0,05)$, begitu juga untuk ukuran korpus luteum dan onset berahi. Hal ini menunjukkan bahwa pemberian CS-NPh secara nasal spray dapat digunakan dalam meningkatkan induksi ovulasi pada sapi perah.
\end{abstract}

Kata Kunci: Nanopartikel, hCG, Nasal Spray, Ovulasi

\begin{abstract}
Pamungkas FA, Sianturi RG, Wina E, Kusumaningrum DA. 2016. Chitosan nanoparticle of hCG (Human Chorionic Gonadotrophin) hormone in increasing induction of dairy cattle ovulation. JITV 21(1): 34-40. DOI: http://dx.doi.org/10.14334/jitv.v21i1.1343

A controlled release delivery system of human chorionic gonadotropin (hCG) hormone helps to overcome the rapid degradation of hCG hormone in the blood, to avoid the use of multiple injections for ovulation induction and to enhance reproductive efficacy. This study aimed to prepare chitosan nanoparticles hCG $(\mathrm{CS}-\mathrm{NPh})$ and to determine its efficacy as nasal spray of CS-NPh. The observed parameters include physico-chemical characteristics of CS-NPh and the follicle size, corpus luteum, the time of ovulation and onset of estrus performed after administration of $\mathrm{CS}-\mathrm{NPh}$ as a nasal spray compared with intramuscular hCG (control) at a dose of 1,000 IU in dairy cattles. The result showed that the formation of the hormone hCG nanoparticles is still in the size range of nanoparticles with a well and more stable molecular mass distribution, so it can be used as a carrier component of hormones. The result showed that the time of ovulation after hCG by intramuscular (day to 3.13 \pm 0.35 ) and CS-NPh as a nasal spray (days to $3.33 \pm 0.49$ ) with the follicle size by $1.62 \pm 0.22$ and $1.76 \pm 0.28 \mathrm{~cm}$ showed no significant differences ( $p>0.05$ ), likewise the size of the corpus luteum and onset of oestrus.. This indicates that administration of CS-NPh as a nasal spray can be used in enhancing the induction of ovulation in dairy cattles.
\end{abstract}

Key Words: Nanoparticles, hCG, Nasal Spray, Ovulation

\section{INTRODUCTION}

Estrus synchronization in dairy cattle is used for facilitating artificial insemination application, saving labor and time in detecting estrus. Estrus synchronization is one way of controlling estrus, to synchronize pre-ovulation condition, minimize variation of follicle maturity, luteolysis and increase estrus at the same time which around 20.5 days of estrus interval and ovulation (Cavalieri et al. 2004). In general, pregnancy rate of Artificial Insemination (AI) after an estrus synchronization in cattle was not as expected or not consistent due to varied of estrus and ovulation time determination due to long estrous cycle in cattle (Roelofs et al. 2005).

Induction of ovulation using Human Chorionic Gonadotropin (hCG) hormone injection together with estrus synchronization program enabled to determine accuracy of estrus and ovulation time which eventually gets improving animal fertility (Johnson et al. 2010). 
Beside giving stress to animal, hCG has fast degradation of endopeptidase and exopeptidase in pituitary. Another approach is using slow release delivery system through implantation method. Hormone content packed or attached on matrix nanoparticle using biodegradable polymer has been used as potential hormone carrier by its capability to improve hormone stability and protected from rapid degradation during hormone transportation and controlling of bioactive agent releasing (Bhadra et al. 2002; Vila et al. 2002; Kommareddy et al. 2005; Rather et al. 2013).

The nasal route has received a great deal of attention as a convenient and reliable method for the systemic administration of drugs. Nasal delivery has been explored as an alternative administration route to target drugs directly to the brain via the olfactory neurons (Ulrika et al. 2005). Nasal mucociliary clearance is one of the most important limiting factors for nasal drug delivery. It severely limits the time allowed for drug absorption to occur and effectively rules out sustained nasal drug administration. However, bioadhesive polymers can be used to increase the nasal residence time, thus allowing longer absorption times, and to achieve a more intimate contact with the nasal mucosa, which results in a higher concentration gradient and subsequent increased absorption (Ugwoke et al. 2005).

Another important limiting factor in the nasal application is the low permeability of the nasal mucosa for the drugs. It seems to be necessary to consider an absorption enhancement mechanism for coadministration of drugs with either mucoadhesive polymers or penetration enhancers or combination of the two (Vasir et al. 2003). Chitosan nanoparticle may strongly bind negatively charged materials such as cell surface and mucosal fluid. Mucosal fluid contained mucin which had different chemical composition, however, some consisted of significant proportion from sialic acid. In physiological condition, sialic acid carried negative charge causing strong electrostatic interaction between mucin and chitosan in soluble (Dhawan et al. 2004).

The purposes of this study were to prepare chitosan nanoparticle of hCG hormone and to determine its effectivity through its use as nasal spray by observing the functional response such as follicle growth, ovulation time, and emergence of estrous signs.

\section{MATERIALS AND METHODS}

Preparation and characterization of chitosan nanoparticle of hCG hormone (CS-NPh) were conducted in the Reproduction Laboratory of the Indonesian Research Institute for Animal Production (IRIAP) and Nanotechnology Laboratory of Indonesian Center for Agricultural Post Harvest Research and Development (ICAPOSTRD). At the same time, in vitro examination was conducted in of the Animal House of IRIAP.

\section{Formulation of chitosan nanoparticle of hCG hormone}

Chemical materials used in formulation of chitosan nanoparticle of hCG were Chitosan (degree of deacetylation $\geq 75 \%$ ) and sodium tripolyphosphate (TPP) produced by Sigma-Aldrich Corporation (St. Louis, MN), acetic acid (glacial) produced by Merck Millipore Corporation (Darmstadt, Jerman), hCG hormone $\left(\right.$ Choluron $\left.^{\circledR}\right)$ produced by Intervet/Merck Animal Health, Holland.

Chitosan nanoparticle of hCG hormone was arranged by ionic interaction process, in accordance with modified procedure performed by Wang et al. (2008). Two solution were prepared, namely $0.2 \% \mathrm{~b} / \mathrm{v}$ of chitosan in $1 \% \mathrm{v} / \mathrm{v}$ acetat acid, and TPP $(0.1 \% \mathrm{~b} / \mathrm{v})$ that diluted in aquadest. TPP $(2.0 \mathrm{ml})$ solution was slowly added using syringe into acetic acid chitosan solution $(5.0 \mathrm{ml})$ under $1500-\mathrm{rpm}$ speed magnetic stirring until nanoparticle formed. Then hCG hormone $\left(\right.$ Choluron $\left.{ }^{\circledR}\right)$ was added slowly into chitosan nanoparticle solution with concentration established was $500 \mathrm{IU} / \mathrm{ml}$ under $1500 \mathrm{rpm}$ speed magnetic stirring for 10 minutes. As $1 \mathrm{~N} \mathrm{HCL}$ or $\mathrm{NaOH}$ solution was added to manage suspension $\mathrm{pH}$ at 5.5.

\section{Characteristics of physicochemical properties of chitosan nanoparticle of hCG hormone}

Average size of particle and distribution were measured by photon correlation spectroscopy (PCS, dynamic light scattering, DLS) technique which is a multipurpose tool to estimate distribution of fine particle size of a material in range $0.6 \mathrm{~nm}-7 \mu \mathrm{m}$. As 5 $\mu \mathrm{m}$ nanoconjugate suspension was diluted in $5 \mathrm{ml}$ deionized water and be shaken slowly and then put into analyzer. After reaching expected intensity, analysis was conducted to obtain average particle size and polydispersity index (PDI) of the samples. Measurement of zeta potential was a way to know the stability of every coloid system which determined by electrophoretic light scattering (ELS).

\section{Evaluation of entrapment efficiency of chitosan nanoparticle of hCG hormone}

Entrapment efficiency (EE) process was determined by separating nanoparticle from suspension that consisting hCG non-entraped with ultra-centrifugation at $12.000 \mathrm{rpm}, 10^{\circ} \mathrm{C}$ for 10 minutes. The amount of free hCG hormone in supernatant was measured by spectrophotometry UV at $\lambda=260 \mathrm{~nm}$ (Katas et al. 
2013). Entrapment efficiency (EE\%) of hCG in CS-NPh was calculated according the following formula:

$\mathrm{EE} \%=\frac{\text { hCG amount }- \text { free hCG in supernatant }}{\text { Total amount of hCG }} 100$

\section{Estrus-ovulation synchronization}

Cows used were 2-5 years old Friesian Holstein $(\mathrm{FH})$, at least experienced once bear, non pregnant one, and had normal estrus cycle. They were ultrasound (USG) first, to monitor ovaries and examine their follicles and corpus luteum (CL) condition, Cows, then injected with Prostaglandin / $\mathrm{PGF}_{2 \alpha}$ (Lutalyse ${ }^{\circledR}$ 5-ml) intramuscularly (IM) and repeated at day 11 . Then, they were divided into 2 groups as following:

Group A : Injected by $1.000 \mathrm{IU}$ hCG hormone intramuscularly at day 2 after the last Prostaglandin $\left(\mathrm{PGF}_{2 \alpha}\right)$ injection

Group B : Chitosan nanoparticle of hCG (CS$\mathrm{NPh}$ ) providing at $1.000 \mathrm{IU}$ by nasal spray at day 2 after the last $\mathrm{PGF}_{2 \alpha}$ injection

\section{Ultrasonography}

USG was conducted to observe the ovarian dynamics, by measuring diameter of follicles and CL development. Diameter development pattern of follicles and CL were monitored using Ultrasonography (brand SIUI Veterinary model CST $7700 \mathrm{~V}$ with 10.4 inchi monitor LCD and Linier Rectal Probe $7.5 \mathrm{MHz}$ ). USG observation was performed everyday started from second $\mathrm{PGF}_{2 \alpha}$ injection until ovulation. Before the transrectal USG observation, cow's feces were emptied and dragged first from the rectum. Scanning was conducted to right and left ovarium, and diameter of entire visible follicles and CL were measured one by one.

\section{Estrus observation}

Observation of estrus was conducted along with USG observation. It was focusedon physical changes of outside reproduction organs during estrus observation such as swelling of vulva, mucus discharged from vulva, reddening of vagina mucous, and it was warm if touched.

\section{Data analysis}

Data were analysed by Analysis of Variance (ANOVA) and then continued by Dunnet further testing. Data were processed by SPSS version 19.

\section{RESULT AND DISCUSSION}

Chitosan nanoparticle of hCG in this study was prepared according to ionic interaction process (ionic gelation), where the process of nanoparticle production depend on positively charged particles dissolved in chitosan molecule while $\mathrm{pH}$ had an important role during its production process. Characteristic of physicochemical properties of chitosan nanoparticle hCG hormone was showed in Table 1.

Table 1. Characteristic of physiochemical properties of chitosan nanoparticle of hCG hormone

\begin{tabular}{lc}
\hline \hline Parameters & Value \\
\hline Particle size (nm) & $226.17 \pm 26.27$ \\
Polydispersity index & $0.301 \pm 0.03$ \\
Zeta potential (mV) & $+21.22 \pm 1.51$ \\
entrapment efficiency $(\%)$ & $54.11 \pm 12.94$
\end{tabular}

Acidity of chitosan nanoparticle-hCG hormone formed was at initial $\mathrm{pH} 3.79 \pm 0.04$ (not shown in the table) and adjusted to $\mathrm{pH}$ 5.5. Therefore, the uptake of nanoparticle close to neutral $\mathrm{pH}$ may prove useful in the controlled release of a drug from a $\mathrm{pH}$-sensitive. Low $\mathrm{pH}$ is a well known sensory irritant in pathological conditions such as inflammation in the nasal mucosa. Acid exposure cause marked nasal irritation via a specific subset of sensory nerves (Dalton et al. 2010). Chitosan in acid media might interact with negatively charged TPP form inter and intra-moleculs producing crossed ionic-chitosan nanoparticle (De Campos et al. 2001; Xu \& Du 2003). Mi et al. (2003) reported that TPP diluted in water separated hydroxide ion (OH-) and tripolyphosphoric (P3O105-and HP3O104) at $\mathrm{pH}$ 9. At basic $\mathrm{pH}$, both hydroxide and tripolyphosphoric ions competed in ionic reaction with protoned-amino group $(\mathrm{NH} 3+)$ from chitosan solution ( $\mathrm{pH}$ 3.5) with deprotonation or crossed-ion. Availability of protonedamino group caused crossed-ionic process easier for chitosan with high deacetilation rate (Agnihotri et al. 2004). Ionic gelation method, nanoparticle was produced by spontantenous formation from smaller size with positive charge (De Campos et al. 2001; Pan et al. 2002) at room themperature (Hu et al. 2002).

Nanoparticle formation by conditioning TPP at acid $\mathrm{pH}(<6)$ resulting low cutting level of phosphor chain and formation of nanoparticle by crossed-ion processing. Dudhani \& Kosaraju (2010) reported that formation of chitosan nanoparticle at $\mathrm{pH} 4.5$, reduced the size of particle and increasing zeta potential than the one formed at pH 5.5. Zengshuan et al. (2002) reported 
that efficiency of insulin hormone interaction with chitosan nanoparticle at $\mathrm{pH} 5.3$ was lower than at $\mathrm{pH}$ 6.1 but had stronger and more stable charge interaction in acidic and enzymatic hydrolysis condition.

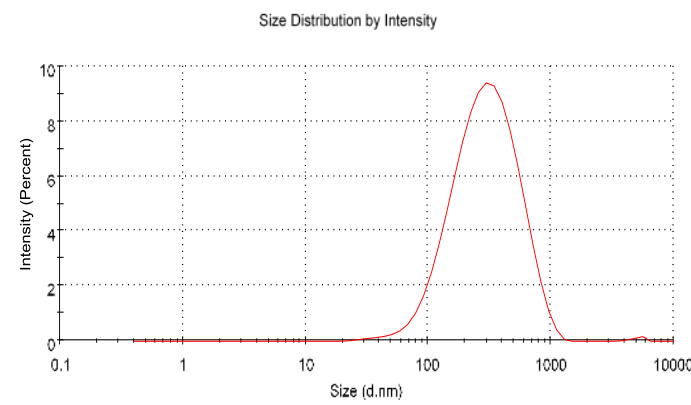

Figure 1. Particle size distributions of chitosan nanoparticles of hCG hormone

nanoparticles hCG hormone is given in Tabel 1 and Figure 1 . The results of this study showed that particle size of chitosan nanoparticle- hCG hormone was $226.17 \pm 26.27 \mathrm{~nm}$ and polydispersity index (PDI) value was $0.301 \pm 0.03$. Particle size is the most important characteristic in nanoparticle system. Particle size in this study was in range with nanoparticle size reported by Mohanraj \& Chen (2006) who said that nanoparticle was a dispersion or solid particle around 10-1000 nm size. As polydispersity index score was in size range of distribution of muleculer mass in certain sample. Result showed that PDI score was 0.3, where this score showed that calculation result of average molecule weight was divided by amount of average molecule weight. The closer to zero means that the distribution was getting better.

Average particle size in this study was higher than Zhang et al. (2004) who reported that low molecular weight chitosan with concentration by $0.1 \%(\mathrm{w} / \mathrm{w})$ in nanoparticle formation resulting distribution of particle size by 153-500 nm. Dudhani \& Kosaraju (2010) reported that formation of catechin chitosan nanoparticle at $\mathrm{pH} 5.5$ resulted particle size as $130 \pm 5$ nm. Rather et al. (2013) said that particle size of chitosan nanoparticle of Luteinizing Hormone Releasing Hormone (LHRH) at pH 6.5 was $114 \pm 10.3$ $\mathrm{nm}$ with PDI score 0.335 . In contrast with Zengshuan et al. (2002) who reported that formation of chitosan nanoparticle of insulin hormone at $\mathrm{pH} 5.3$ resulting particle size by $243-271 \mathrm{~nm}$ with $0.50-0.57$ of PDI score. Difference of average particle size and PDI score was due to difference in $\mathrm{pH}$ and the hormone used. Zhang et al. (2004) reported that manipulation of charged particle might be performed with varied $\mathrm{pH}$ but was followed by disintegration of particle due to weak interaction of chitosan and TPP (Zhang \& Kosaraju, 2007).
Surface charge is an important parameter to examine stability of suspention and adhesion of particular system in biological surface, so that evaluation of zeta potential should be an important part of nanoparticle. Zeta potential was a surface charge that might influence stability of particle in suspention due to electrostatic repulsion between particles (Qi et al. 2004). Zeta potential and entrapment efficiency of chitosan nanoparticle- hCG in this study were $+21.22 \pm 1.51 \mathrm{mV}$ and $54.11 \pm 12.94 \%$, respectively.

Analysis of zeta of chitosan nanoparticle-hCG in this study showed positive (+) sign and more than 20 mv. Positively charged-chitosan nanoparticle was a uniq characterization of chitosan/TPP particle. In a formation mechanism of particle, positively chargedamina was neutralized by its interaction with negative charge in triphosphaste molecule and recidual amino group affecting positive zeta potential (Honary \& Zahir 2013). Higher zeta potency value in certain range indicated that chitosan nanoparticle formed was not stable. Wang et al. (2008) said that long amino chain group might prevent aggregation in nanoparticle.

hCG hormone was a glycoprotein hormone which able to efficiently (90-100\%) absorb into polimer at around isoelectric $\mathrm{pH}(\mathrm{pI})$ of protein due to minimalization electrostatic repulsion which increasing of stability conformation and shorter specific surface wide of protein molecule (Sanchez et al. 2008). Relation of hCG hormone and chitosan might be encouraged by hydrophobic interaction between $-\mathrm{H}$ bond, however its association was relatively unstable due to $\mathrm{pH}$ change in acid range (Nielsen et al. 2001). Wang et al. (2008) reported that chitosan nanoparticle of estradiol hormone prepared by ionic glass method had zeta potential score and entrapment efficiency by $+25.4 \mathrm{mV}$ and $67 \%$ respectively. While, Rather et al. (2013) said that chitosan nanoparticle of Luetinizing hormone releasing hormone (LHRH), with same method resulted zeta potention score and entrapment efficiency by $-33.14 \pm 6.67 \mathrm{mV}$ and $69 \%$ respectively.

In vivo study was conducted to analyze the application method of chitosan nanoparticle-hCG hormone (CS-NPh) by nasal spray. Absorption in the nasal cavity was faster and there was a direct tract from the nasal cavity to central nerve system increasing hormone capacity selectively in certain area in brain (Wang et al. 2008). Many studies in experimental animal showed that hormone concentration in brain was higher after hormone application via nasal than via intravena injection that showing a tract from nasal to brain (Illum 2000; Vyas et al. 2005). Chitosan nanoparticle may strongly bind materials such as cell surface and mucus. Mucus consisted of mucin which has different chemical construction, however some of them consisted of different silate acid. At physiologic$\mathrm{pH}$, silate acid carried negative charge causing strong 
interaction between mucin and chitosan in solution (Dhawan et al. 2004). Chitosan not only served to enhance adhesive between formulation and nasal tissue, but also acted in paracellular transportation process (Smith et al. 2004). Immunohistological studies have shown that chitosan can open the tight junctions between cells through an effect upon factin filaments. Unlike other absorption promoters, chitosan appears to be non-toxic and well tolerated by human subjects. This combination of bioadhesion and paracellular transport effects has led to a consideration of the use of chitosan for the delivery hormone via the nasal cavity (Wang et al. 2008).

Thirteenth of 43 synchronized-cows showed ovulation time before hCG providing, so that only 30 cows were included in the treatment group. This possibility due to cows already in luteal phase and already had CL after second $\mathrm{PGF}_{2 \alpha}$ injection, so that PGF2 $\alpha$ acted to the CL. The lysis of CL decreased the progesterone level and causing loss barrier against gonadotropine hormone which induced follicle growth and maturation, estrus and ovulation. As said by Marietta et al. (2001) that $\mathrm{PGF}_{2 \alpha}$ hormone use for estrus syncrionization program was only effective if the animals already hada a CL. Then Santos et al. (2001) said that $\mathrm{PGF}_{2 \alpha}$ injection would decrease concentration of progesterone in blood so that ratio of concentration of estrogen and progesterone increased inducing animals showing estrus behaviour and then ovulation occured.
Ovulated follicle size and ovulation time after hCG injection intramuscularly and $\mathrm{CS}-\mathrm{NPh}$ as a nasal spray showed in Table 2. Research result showed that hCG hormone intramuscularly injection and $\mathrm{CS}-\mathrm{NPh}$ as a nasal spray did not show any significant difference (P>0.05) both in size of ovulated follicle and its ovulation time. Times of ovulation after hCG providing intramuscularly and $\mathrm{CS}-\mathrm{NPh}$ as a nasal spray were at the day- $3.13 \pm 0.35$ and $3.33 \pm 0.49$ days, respectively with size of ovulated follicle was $1.62 \pm 0.22$ and $1.76 \pm 0.28 \mathrm{~cm}$, respectively. Time of ovulation related to the largest diameter follicle. Safilho et al. (2010) and Perry et al. (2005) reported that follicle ovulated in cattle, generally had diameter around 1.11-1.44 cm. Whereas, Cavalieri et al. (2004) reported that diameter of follicle ovulated in FH cattle was around 1.06-1.76 $\mathrm{cm}$.

Beside follicle size observation, corpus luteum size and estrus onset observation after hCG applying were conducted and presented in Table 3. It shows that administration of hCG intramuscularly and CS-NPh by nasal spray did not show any significant difference $(\mathrm{P}>0 / 05)$ both in corpus luteum size or onset of estrus. The results of this research also showed that corpus luteum size decreased from day- 0 to day- 4 after the last PGF2 $\alpha$ injection and hCG by IM (from $2.05 \pm 0.46$ into $0.91 \pm 0.26 \mathrm{~cm}$ ) and $\mathrm{CS}-\mathrm{NPh}$ as a nasal spray (from $2.16 \pm 0.40$ into $0.88 \pm 0.22 \mathrm{~cm})$.

Principle of estrus synchronization using $\mathrm{PGF}_{2 \alpha}$ which act as luteolytic agent was regressing CL and causing loss of $\mathrm{CL}$ function and decline the

Table 2. Size of folicle ovulated and ovulation after hCG hormone providing

\begin{tabular}{|c|c|c|c|c|c|c|}
\hline \multirow{2}{*}{ Group } & \multirow{2}{*}{$\mathrm{n}$} & \multicolumn{4}{|c|}{ Folicle size (cm) } & \multirow{2}{*}{ Ovulation time (6th day) } \\
\hline & & HO & $\mathrm{H} 1$ & $\mathrm{H} 2$ & Before ovulation & \\
\hline A & 15 & $1.22 \pm 0.20$ & $1.40 \pm 0.20$ & $1.49 \pm 0.21$ & $1.62 \pm 0.22$ & $3.13 \pm 0.35$ \\
\hline B & 15 & $1.25 \pm 0.25$ & $1.42 \pm 0.28$ & $1.56 \pm 0.28$ & $1.76 \pm 0.28$ & $3.33 \pm 0.49$ \\
\hline
\end{tabular}

Description: A : 1.000 IU hCG hormone providing intramuscularly

B : $1.000 \mathrm{IU} \mathrm{CS}-\mathrm{NPh}$ providing by nasal spray

$\mathrm{H} 0$ : the last day of $\mathrm{PGF}_{2 \alpha}$ injection

$\mathrm{H} 1$ :-H2: day-1 to day-2 after the last $\mathrm{PGF}_{2 \alpha}$ injection

Table 3. Size of corpus lutheum and onset estrus after hCG hormone providing

\begin{tabular}{cccccccc}
\hline \hline \multirow{2}{*}{ Group } & \multirow{6}{c}{$\mathrm{n}$} & \multicolumn{5}{c}{ Size of corpus lutheum $(\mathrm{cm})$} & \multirow{2}{*}{ Ovulation time (days) } \\
\cline { 3 - 7 } & & $\mathrm{H} 0$ & $\mathrm{H} 1$ & $\mathrm{H} 2$ & $\mathrm{H} 3$ & $\mathrm{H} 4$ & \\
\hline $\mathrm{A}$ & 15 & $2.05 \pm 0.46$ & $1.63 \pm 0.38$ & $1.34 \pm 0.33$ & $1.11 \pm 0.27$ & $0.91 \pm 0.26$ & $2.85 \pm 0.90$ \\
$\mathrm{~B}$ & 15 & $2.16 \pm 0.40$ & $1.69 \pm 0.30$ & $1.36 \pm 0.37$ & $1.16 \pm 0.38$ & $0.88 \pm 0.22$ & $2.62 \pm 0.77$ \\
\hline
\end{tabular}

Description: A : 1.000 IU hCG hormone providing intramuscularly

B : : 1.000 IU CS-NPh providing by nasal spray

$\mathrm{H} 0$ : the last day of $\mathrm{PGF}_{2 \alpha}$ hormone injection

$\mathrm{H} 1-\mathrm{H} 2$ : day-1 to day-2 after the last $\mathrm{PGF}_{2 \alpha}$ injection 
progesterone concentration, against gonadotropine and there was a growth and maturation of follicle. Beside regressing $\mathrm{CL}, \mathrm{PGF}_{2 \alpha}$ also decreased concentration of progesterone to less than $1.0 \mathrm{ng} / \mathrm{ml}$ within 24 hours (Yoshida \& Nakao 2005). During estrus cycle, CL was an important structure in the term of size and duration. Appearance and disappearance of CL were responsible to estrus cycle (Hafez \& Hafez 2001; Senger 2005). Estrus syncrhonization in animal was aimed to simultaneous their estrus in the same time. Research result showed that the emergence of estrus signs (swelling of vulva, mucus discharged from vulva, reddening of vagina mucousm, and it was warm if touched) after hCG providing intramuscularly and nasal spray was at the day- $2.85 \pm 0.90$ and $2.62 \pm 0.77$, respectively did not showing any significant difference $(\mathrm{P}>0.05)$.

\section{CONCLUSION}

Characteristic of chemical properties of particle size, polydispersity index, zeta potential and entrapment efficiency of chitosan nanoparticle of hCG hormone showed that nanoparticle formation of hCG hormone using chitosan polimer was still in nanoparticle size range and might be used as hormone carrier component.

Research result showed that time of ovulation after hCG providing intramuscularly (day- 3.13 \pm 0.35 ) and CS-NPh by nasal spray (day- $3.33 \pm 0.49$ ) with size of follicles ovulated were $1.62 \pm 0.22$ and $1.76 \pm 0.28 \mathrm{~cm}$, respectively. Size of corpus luteum decreased from day0 to day-4 after hCG providing intramuscularly (from $2.05 \pm 0.46$ into $0.91 \pm 0.26 \mathrm{~cm}$ ) or $\mathrm{CS}-\mathrm{NPh}$ as a nasal spray (from $2.16 \pm 0.40$ into $0.88 \pm 0.22 \mathrm{~cm}$ ). As well as estrus onset and level of progesterone hormone after hCG providing intramuscularly did not show any significant difference $(\mathrm{P}>0.05)$ with $\mathrm{CS}-\mathrm{NPh}$ as a nasal spray. This showed that $\mathrm{CS}-\mathrm{NPh}$ providing as a nasal spray can be used in increasing induction of ovulation in dairy cattle.

\section{ACKNOWLEDGEMENTS}

This study was supported in part by DIPA from Indonesian Research Institute for Animal Production T.A. 2015 No. 1806.018.003/K-4/APBN 2015. The authors wish to thank M. Syaeri, Enok Mardiyah, Aqdi Faturahman Arrazy, Nia and Yanti for technical assistance and performing assays.

\section{REFERENCES}

Agnihotri SA, Mallikarjuna NN, Aminabhavi TM. 2004. Recent advances on chitosan-based micro- and nanoparticles in drug delivery. J Controlled Release. 100:5-28.

Bhadra D, Bhadra S, Jain P, Jain NK. 2002. Pegnology: a review of PEG-ylated systems. Pharmazie. 57:5-29.

Cavalieri J, Hepworth G, Macmillan KL. 2004. Ovarian follicular development in Holstein cows following synchronisation of oestrus with oestradiol benzoate and an intravaginal progesterone releasing insert for 5-9 days and duration of the oestrous cycle and concentrations of progesterone following ovulation. Anim Reprod Sci. 81:177-193.

Dalton PH, Opiekun RE, Gould M, McDermott R. Wilson T, Maute C, Ozdener MH, Zhao K, Emmett E, Lees PSJ, Herbert R, Moline J. 2010. Chemosensory loss: functional consequences of the world trade center disaster. Environ Health Perspect. 118:1251-1256.

De Campos AM, Sanchez A, Alonso MJ. 2001. Chitosan nanoparticles: A new vehicle for the improvement of the delivery of drugs to the ocular surface. Application to cyclosporin A. Int J Pharm. 224:159-168.

Dhawan S, Singla AK, Sinha VR. 2004. Evaluation of mucoadhesive properties of chitosan microspheres prepared by different methods. AAPS Pharm Sci Tech. 5:122-128.

Dudhani AR, Kosaraju SL. 2010. Bioadhesive chitosan nanoparticles: Preparation and characterization. Carbohydrate Polymer. 81:243-251.

Hafez ESE, Hafez B. 2001. Reproduction in farm animals. 7th ed. Philadelphia (USA): Lippincot Williams \& Wilkins.

Honary S, Zahir F. 2013. Effect of zeta potential on the properties of nano-drug delivery systems-a review (Part 1). Trop J Pharm Res. 12:255-264.

Hu Y, Jiang X, Ding Y, Ge H, Yuan Y, Yang C. 2002. Synthesis and characterization of chitosan-poly (acrylic acid) nanoparticles. Biomaterials. 23:3193-3201.

Illum L. 2000. Transport of drugs from the nasal cavity to the central nervous system. Eur J Pharm Sci. 11:1-18.

Johnson R, William AB, Evelin JC, Victor N, Yoonsung J, Melissa M. 2010. Roles of hCG in advancing follicular growth to ovulation after concurrent injections of PGF2 $\alpha$ and GnRH in postpubertal Holstein heifers bearing a CL. Vet Medic Int. 2010:1-7.

Katas H, Raja MAG, Lam KL. 2013. Development of chitosan nanoparticles as a stable drug delivery system for protein/siRN. Int J Biomater. 2013:1-9. doi: $10.1155 / 2013 / 146320$.

Kommareddy S, Tiwari SB, Amiji MM. 2005. Longcirculating polymeric nanovectors for tumor-selective gene delivery. Technol Cancer Res Treat. 4:615-625.

Marietta FW, Sayre B, Inskeep EK, Flores JA. 2001. Prostaglandin F2 $\alpha$ regulation of the bovine corpus luteum endothelin system during the early and midluteal phase. Biol Reprod. 65:1710-1717. 
Mi FL, Sung HW, Shyu SS, Su CC, Peng CK. 2003. Synthesis and characterization of biodegradable TPP/genipin co-crosslinked chitosan gel beads. Polymer. 44:6521-6530.

Mohanraj VJ, Chen Y. 2006. Nanoparticles - a review. Tropic J Pharm Res. 5:561-573.

Nielsen L, Khurana R, Coats A, Frokjaer S, Brange J, Vyas S, Uversky V, Fink AL. 2001. Effect of environmental factors on the kinetics of insulin fibril formation: Elucidation of the molecular mechanism. Biochemistry. 40:6036-6046.

Pan Y, Li Y, Zhao H, Zheng J, Xu H, Wei G. 2002. Bioadhesive polysaccharide in protein delivery system: Chitosan nanoparticles improve the intestinal absorption of insulin in vivo. Int J Pharm. 249:139-147.

Perry GA, Smith MF, Lucy MC, Green JA, Parks TE, Macneil MD, Roberts AJ, Geary TW. 2005. Relationship between follicle size at insemination and pregnancy success. Proc Natl Acad Sci. 102:5268-5273.

Qi L, Xu Z, Jiang X, Hu C, Zou X. 2004. Preparation and antibacterial activity of chitosan nanoparticles. Carbohydrate Res. 339:2693-2700.

Rather MA, Rupam S, Subodh G, Ferosekhan S, Ramya VL, Sanjay BJ. 2013. Chitosan-nanoconjugated hormone nanoparticles for sustained surge of gonadotropins and enhanced reproductive output in female fish. Plos One. $8: 1-11$.

Roelofs JB, van Eerdenburg FJCM, Soede NM, Kemp. 2005. Various behavioral signs of estrous and their relationship with time of ovulation in dairy cattle. Theriogenology. 63:1366-1377.

Safilho MF, Crespilho AM, Santos JEP, Perry GA, Baruselli PS. 2010. Ovarian follicle diameter at timed insemination and estrous response influence likelihood of ovulation and pregnancy after estrous synchronization with progesterone or progestin-based protocols in suckled Bos indicus cows. Anim Reprod. Sci. 120:23-30.

Sanchez S, Roldan M, Perez S, Fabregas E. 2008. Toward a fast, easy, and versatile immobilization of biomolecules into carbon nanotube/polysulfone-based biosensors for the detection of hCG hormone. Anal Chem. 80:65086514.

Santos JEP, Thatcher WW, Pool L, Ovrton MW. 2001. Effect of human chorionic gonadotropin on luteal function and reproductive performance of high producing lactating Holstein dairy cow. J Anim Sci. 79:2881-2894.
Senger PL. 2005. Pathways to pregnancy and parturition. 2nd ed. Moscow (Russia): Current Conception Inc.

Smith J, Edward W, Michael D. 2004. Effect of Chitosan on Epithelial Cell Tight Junctions. Pharm Res. 21:43-49.

Ugwoke MI, Agu RU, Verbeke Nb, Kinget R. 2005. Nasal mucoadhesive drug delivery: Background, applications, trends and future perspectives. Adv Drug Deliv Rev. 57:1640-1665.

Ulrika W, P. Elena, J. Björn. 2005. Transfer of morphine along the olfactory pathway to the central nervous system after nasal administration to rodents. Eur $\mathbf{J}$ Pharm Sci. 24:565-573.

Vasir JK, Tambwekar K, Garg S. 2003. Bioadhesive microspheres as a controlled drug delivery system. Int $\mathrm{J}$ Pharm. 255:13-32.

Vila A, Sanchez A, Tobio M, Calvo P, Alonso MJ. 2002. Design of biodegradable particles for protein delivery. $\mathrm{J}$ Control Release. 78:15-24.

Vyas TK, Aliasgar S, Sudhanva M, Ambikanandan M. 2005. Intranasal drug delivery for brain targeting. Current Drug Delivery. 2:165-175.

Wang, X.M, N. Chi, X. Tang. 2008. Preparation of estradiol chitosan nanoparticles from improving nasal absorption and brain targeting. Eur J Pharma Biopharma. 70:735740 .

Xu Y, Du Y. 2003. Effect of molecular structure of chitosan on protein delivery properties of chitosan nanoparticles. Int J Pharm. 250: 215-226.

Yoshida C, Nakao T. 2005. Response of plasma cortisol and progesterone after ACTH challenge in ovariectomized lactating dairy cows. J Reprod Dev. 51:99-107.

Zengshuan MA, Yeoh HH, Lee YL. 2002. Formulation pH modulates the interaction of insulin with chitosan nanoparticles. J Pharm Sci. 91: 1396-1404.

Zhang Q, Jiang X, Jiang W, Lu W, Su L, Shi Z. 2004. Preparation of nimodipineloaded microemulsion for intranasal delivery and evaluation of the targeting efficiency to brain. Int J Pharm. 275:85-96.

Zhang H, Oh M, Allen C, Kumacheva E. 2004. Monodisperse chitosan nanoparticles for mucosal drug delivery. Biomacromolecules. 5:2461-2468.

Zhang L, Kosaraju SL. 2007. Biopolymeric delivery system for controlled release of polyphenolic antioxidants. Eur Polymer J. 43:2956-2966. 